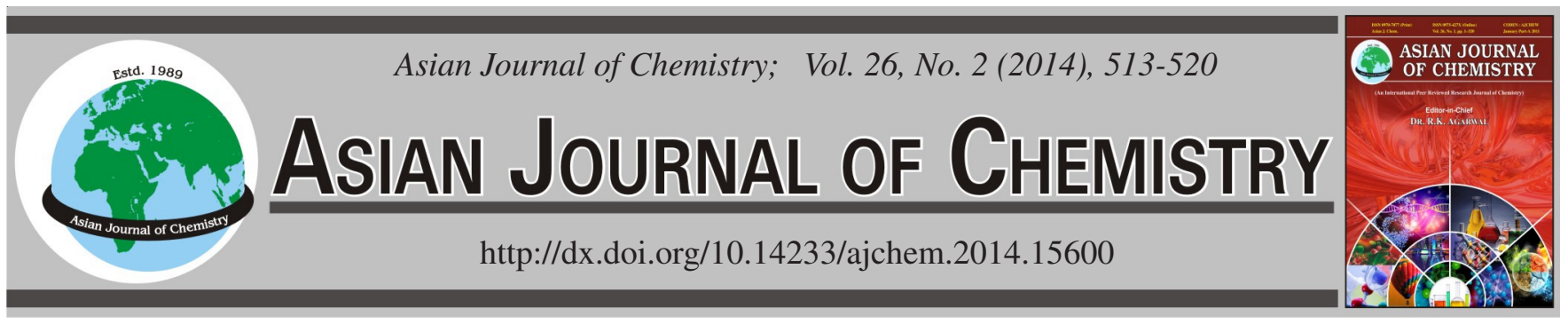

\title{
Synthesis, Characterization and Antimicrobial Activity of Three Gallates Containing Imidazole, Benzimidazole and Triclosan Units
}

\author{
ZhIYUAN WANG ${ }^{1,2}$, HaIBIN Gu ${ }^{1,2, *}$ and WUYONG ChEN $^{1,2}$
}

\begin{abstract}
${ }^{1}$ Key Laboratory of Leather Chemistry and Engineering of Ministry of Education, Sichuan University, Chengdu 610065, P.R. China ${ }^{2}$ National Engineering Laboratory for Clean Technology of Leather Manufacture, Sichuan University, Chengdu 610065, P.R. China

*Corresponding author: Fax: +86 28 85405237; Tel: +8628 85404462; E-mail: guhaibing@ @scu.edu.cn
\end{abstract}

\begin{abstract}
Three new gallates containing the antimicrobial units of imidazole, benzimidazole and triclosan, respectively, were designed and synthesized. Firstly, the direct esterification method, in which $p$-toluenesulfonic acid was used as the catalyst, was adopted to synthesize the three gallates. Results show that it is infeasible to obtain the target products, especially for the direct esterification reaction of 5-methyl-2-nitroimidazole-1-ethanol and gallic acid, the synthesized product is just a complex composed by equimolar 5-methyl-2-nitro-imidazole-1ethanol and gallic acid and stabilized by a lot of intramolecular and intermolecular hydrogen bonds, which was proved by the singlecrystal X-ray diffraction analysis. Another, the indirect esterification method, in which the phenolic hydroxyl groups of gallic acid were first protected by acetyls as shown in Scheme-I, was employed. The obtained compounds were proved to be the expected products by elemental analysis, IR, ${ }^{1} \mathrm{H}$ NMR, ${ }^{13} \mathrm{C}$ NMR and X-ray single-crystal diffraction. Finally, the inhibition zone method was used to determine the antimicrobial effect of the synthesized gallates and their initial compounds. Results indicate that the introduction of the three antimicrobial units has obvious synergistic or additive effect on the antimicrobial activities of gallates. The gallates shows different inhibitory effect against different tested microbes, which is mainly decided by the introduced antimicrobial units.
\end{abstract}

Keywords: Gallates, Imidazole, Benzimidazole, Triclosan, Antimicrobial activity, Crystal structure.

\section{INTRODUCTION}

Gallic acid is an important decomposition product of hydrolyzable tannin and shows good biological activities, usually reacts with alcohols to prepare its esterification products because of its poor lipid-solubility ${ }^{1,2}$. The synthesized gallates can effectively eliminate superoxide anion radicals and hydroxyl radicals, so they are generally used as antioxidants for food such as fat and cream ${ }^{1-6}$. Because of its bactericidal action and bactriostasis, gallates are often applied as preservatives for fruits, vegetable and $\operatorname{wood}^{7-12}$. Furthermore, in the area of pharmaceuticals, cosmetic and photosensitive heat-sensitive materials, gallates also finds extensively application ${ }^{1,2,13}$. For example, as a medicine, gallates exhibit some actions to combat platelet aggregation, facilitate fibrinolysis and thrombolysis, dilate the blood vessel and increase blood flow to the coronary artery and have certain curative effect on cardiovascular and cerebrovascular diseases, viral disease, bacterial infections and stomach ulcer ${ }^{1,14-23}$. Consequently, more and more studies have been focused on the synthesis and application of gallates ${ }^{1,2}$.

As the processed products of natural animal hides and skins, leathers are easy to be eroded by bacteria and fungi in the period of processing, storage and wear, which not only lower the grades of leather but also endanger the health of consumers $^{24}$. Therefore, there is an utmost need to develop antimicrobial compounds with broad-spectrum, high efficiency and less toxicity. In the leather industry, natural tannin containing gallates such as Chinese gallnut, valonia, chestnut and myrobalan, are mainly used as tanning agent ${ }^{25}$. Although these natural gallates show certain antimicrobial activities, their performance can not be comparable with the commercial leather fungicides such as 2-(thiocyanomethylthio)benzothiazole (TCMTB $)^{24}$. The purpose of our research program is to improve the antimicrobial activities of gallates by introducing different antimicrobial units into the molecular structure of gallates and estimate the potential of the synthesized compounds as leather antimicrobial agents. In this study, based on the combination principle of active structures, we designed three new gallates containing the antimicrobial units of imidazole, benzimidazole and triclosan, respectively. It is well known that imidazole and benzimidazole derivatives have good antimicrobial activities and they have been widely used as antimicrobial agents in many fields such as medicine and farm chemical ${ }^{26,27}$. Triclosan is also an efficient and safe antimicrobial agent and because 
of its good compatibility with skin, it has been extensively applied in all kinds of daily chemicals containing handwashing, soap, washing powder and mouthwash ${ }^{28,29}$. Accordingly, the new designed gallates may exhibit good antimicrobial properties if the combination of these antimicrobial units and gallic structure shows a significant synergistic inhibition effect against microbes. So, to efficiently synthesize these gallates, we tested two synthetic routes-direct and indirect esterification method (Scheme-I). Elemental analysis, IR, ${ }^{1} \mathrm{H}$ $\mathrm{NMR},{ }^{13} \mathrm{C}$ NMR and X-ray single-crystal diffraction were used to characterize their structures. Furthermore, the antimicrobial activities of the new gallates and their original compounds were compared by determining the diameters of inhibition zones.

\section{EXPERIMENTAL}

Triclosan and 5-methyl-2-nitro-imidazole-1-ethanol were purchased from Kelong Chemicals Co., Ltd, Chengdu, China. Trisacetyl-galloyl chloride (TAGC) was synthesized from gallic acid by the route shown in Scheme-I and its melting point is $107-108^{\circ} \mathrm{C}\left(106-107^{\circ} \mathrm{C}\right)^{9}$. 2-Methylol benzimidazole was synthesized by the reaction of $o$-diaminobenzene and glycolic acid and its melting point is $168-170^{\circ} \mathrm{C}\left(169-171^{\circ} \mathrm{C}\right)^{30}$ All the other reagents used in this experimental were research grade.

Elemental analyses $(\mathrm{C}, \mathrm{H}, \mathrm{N})$ were performed on a CarloErba 1106 analyser. Infrared spectra were obtained on a FT-IR spectrophotometer (MAGNA.IR506, Nicolet Ltd., USA) by using $\mathrm{KBr}$ disk in the range $4000-400 \mathrm{~cm}^{-1}$. Measurement of the crystal was carried out on a CCD X-ray single crystal diffractometer (Xcalibur, Eos, Britain). ${ }^{1} \mathrm{H}$ and ${ }^{13} \mathrm{C} \mathrm{NMR}$ spectra were recorded on a Bruker Avance 600 (or 400) instrument. Chemical shifts were reported as $\delta$ (ppm) relative to TMS as internal standard.

Synthesis of 2,4,4'-trichloro-2'-hydroxy ethyoxyl diphenyl ether: Triclosan $(14.475 \mathrm{~g}, 0.05 \mathrm{~mol})$ and potassium iodide $(0.5 \mathrm{~g}, 0.03 \mathrm{~mol})$ were dissolved in $50 \mathrm{~mL}$ distilled water with $\mathrm{NaOH}(4.0 \mathrm{~g}, 0.1 \mathrm{~mol})$ at room temperature. Then, the temperature was raised to $80^{\circ} \mathrm{C}$ and 2-chloroethanol $(20.13 \mathrm{~g}, 0.25$ mol) was added dropwise over $0.5 \mathrm{~h}$ under mechanical stirring. The mixture was stirred for $3 \mathrm{~h}$ at $80^{\circ} \mathrm{C}$. During this period, the $\mathrm{pH}$ of the mixture is kept at $9-10$ by adding $50 \%(\mathrm{w} / \mathrm{w})$ $\mathrm{NaOH}$ solution. Then, the mixture was cooled to room temperature and $300 \mathrm{~mL}$ distilled water was added. An oily crude product separated out when hydrochloric acid was added to adjust the $\mathrm{pH}$ of the solution to 2-3. After washed by $50 \%$ (w/w) $\mathrm{NaOH}$ solution and then distilled water for three times, the product was purified by recrystallization with ethanol-water $(6: 4, \mathrm{v} / \mathrm{v})$ mixed solvent. $7.5 \mathrm{~g}$ of pure product, which is white needle-like crystal, was obtained and the total yield is $49.9 \%$. m.p. $65-67^{\circ} \mathrm{C}$. Anal. calcd. (\%) for $\mathrm{C}_{14} \mathrm{H}_{11} \mathrm{O}_{3} \mathrm{Cl}_{3}: \mathrm{C}, 50.37 ; \mathrm{H}$, 3.30. Found (\%): C, 51.03; H, 3.30. Slected IR data $\left(\mathrm{KBr}, \mathrm{cm}^{-1}\right)$ : 3367.403258.46 $\left(\mathrm{V}_{\mathrm{CH}_{2}-\mathrm{OH}}\right), 2930.26,2867.28\left(\left(\mathrm{v}_{\mathrm{CH}_{2}}\right), 1597.85\right.$, $1583.31,1493.68\left(v_{\text {benzene }}=\mathrm{C}\right), 1468.77\left(\delta_{\mathrm{CH}_{2}}\right), 1232.02\left(\mathrm{n}_{\mathrm{Ar}-\mathrm{O}-\mathrm{C}}\right)$, $1050.08\left(\mathrm{n}_{\mathrm{CH}_{2}-\mathrm{O}}\right), 1115.86,796.64\left(\mathrm{v}_{\mathrm{Ar}-\mathrm{Cl}}\right), 850.53,833.79\left(\delta_{\mathrm{Ar}-\mathrm{H}}\right)$. ${ }^{1} \mathrm{H}$ NMR $\left(600 \mathrm{MHz}, \mathrm{CDCl}_{3}\right), \delta_{\mathrm{ppm}}: 1.84(\mathrm{~s}, 1 \mathrm{H}, \mathrm{OH}), 3.82(\mathrm{t}$, $\left.2 \mathrm{H},-\mathrm{CH}_{2} \mathrm{O}-\right), 4.07$ (t, $\left.2 \mathrm{H},-\mathrm{OCH}_{2}-\right), 6.72(\mathrm{~d}, 1 \mathrm{H}, \mathrm{Ph}), 6.97$ $(\mathrm{d}+\mathrm{s}, 2 \mathrm{H}, \mathrm{Ph}), 7.01(\mathrm{~s}, 1 \mathrm{H}, \mathrm{Ph}), 7.13(\mathrm{~d}, 1 \mathrm{H}, \mathrm{Ph}), 7.47$ (d, 1H, $\mathrm{Ph}) .{ }^{13} \mathrm{C} \mathrm{NMR}\left(600 \mathrm{MHz}, \mathrm{CDCl}_{3}\right), \delta_{\mathrm{ppm}}: 61.10\left(-\mathrm{CH}_{2} \mathrm{O}-\right), 70.89$ $\left(-\mathrm{OCH}_{2}-\right), 115.43(\mathrm{Ph}), 118.34(\mathrm{Ph}), 121.76(\mathrm{Ph}), 121.89(\mathrm{Ph})$, $124.61(\mathrm{Ph}), 127.84(\mathrm{Ph}), 128.37(\mathrm{Ph}), 130.33(\mathrm{Ph}), 130.56$ $(\mathrm{Ph}), 143.50(\mathrm{Ph}), 150.44(\mathrm{Ph}), 152.23(\mathrm{Ph})$.

Synthesis of gallates by direct esterification method: The reaction between 5-methyl-2-nitro-imidazole-1-ethanol and gallic acid was taken as an example. The catalyst of $p$ toluenesulfonic acid $(6.0 \mathrm{~g}, 0.035 \mathrm{~mol})$ and water-carrying agent of benzene $(30 \mathrm{~mL})$ were added to a solution of gallic acid (10.23 g, $0.06 \mathrm{~mol})$ and 5-methyl-2-nitro-imidazole-1ethanol $(21 \mathrm{~g}, 0.12 \mathrm{~mol})$ in 1,4-dioxane $(300 \mathrm{~mL})$. The mixture was held under Dean-Stark conditions for $8.0 \mathrm{~h}$ before the solvent as well as water-carrying agent were removed under vacuum. The residue was washed by distilled water for three times to remove the catalyst. Then, the crude product was purified by recrystallization with distilled water. A green crystal was obtained and the yield is $62.5 \%$. m.p. $188-190{ }^{\circ} \mathrm{C}$. Anal. calcd. (\%) for $\mathrm{C}_{13} \mathrm{H}_{16} \mathrm{~N}_{3} \mathrm{O}_{8}$ : C, 45.61; H, 4.68; N, 12.28. Found (\%): C, 45.72; H, 5.08; N, 12.45. Slected IR data $\left(\mathrm{KBr}, \mathrm{cm}^{-1}\right)$ : $3299.86\left(\mathrm{v}_{\mathrm{OH}}\right), 3098.87\left(\mathrm{v}_{\mathrm{CH}_{3}}\right), 1682.59\left(\mathrm{v}_{\mathrm{C}=\mathrm{O}}\right), 1533.47$, $1367.65,1352.11\left(\mathrm{v}_{\mathrm{NO}_{2}}\right), 1068.76\left(\mathrm{v}_{\mathrm{CH}_{2}-\mathrm{OH}}\right), 1606.00\left(\mathrm{v}_{\mathrm{C}=\mathrm{N}}\right)$, 1488.23, 1465.55, $1423.63\left(\mathrm{v}_{\mathrm{Ar}}\right) .{ }^{1} \mathrm{H}$ NMR $(600 \mathrm{MHz}$, $\left.\left(\mathrm{CD}_{3}\right)_{2} \mathrm{SO}\right), \delta_{\mathrm{ppm}}: 2.46\left(\mathrm{~s}, 3 \mathrm{H}, \mathrm{CH}_{3}\right), 3.69\left(\mathrm{~m}, 2 \mathrm{H},-\mathrm{CH}_{2} \mathrm{O}-\right)$, 4.36 (t, 2H, - $\left.\mathrm{NCH}_{2}-\right), 5.03$ (t, 1H, C-OH), 6.93 (s, 2H, Ph), $8.03(\mathrm{~s}, 1 \mathrm{H},=\mathrm{CH}$ of imidazole $), 8.86(\mathrm{~s}, 1 \mathrm{H}, \mathrm{Ph}-\mathrm{OH}), 9.20(\mathrm{~s}$, $2 \mathrm{H}, \mathrm{Ph}-\mathrm{OH}), 12.24$ (s, 1H, COOH). ${ }^{13} \mathrm{C} \mathrm{NMR}(600 \mathrm{MHz}$, $\left.\left(\mathrm{CD}_{3}\right)_{2} \mathrm{SO}\right), \delta_{\mathrm{ppm}}: 14.70\left(\mathrm{CH}_{3}\right), 48.72\left(-\mathrm{NCH}_{2}-\right), 60.21\left(-\mathrm{CH}_{2} \mathrm{O}-\right)$, $109.17(\mathrm{Ph}), 120.89$ (=CH of imidazole), $133.43(\mathrm{Ph}), 138.44$ $(\mathrm{N}=\mathrm{C}$ of imidazole), $138.86(\mathrm{Ph}-\mathrm{OH}), 145.86(\mathrm{Ph}-\mathrm{OH}), 152.41$ $\left(\mathrm{C}-\mathrm{NO}_{2}\right), 167.93(\mathrm{COOH})$.

Similar procedure was applied for the other two direct esterification reactions. The product of the direct esterification between 2-methylol benzimidazole and gallic acid is a greyred powder whose IR spectrum is similar to that of 2-methylol benzimidazole. And for the reaction between 2,4,4'-trichloro2'-hydroxy ethyoxyl diphenyl ether and gallic acid, the product is also a grey-red powder whose IR spectrum is similar to that of 2,4,4'-trichloro-2'-hydroxy ethyoxyl diphenyl ether, too. So, this method did not work in the two reactions.

Synthesis of gallates by indirect esterification method: The 2-methylol benzimidazole was taken as an example to

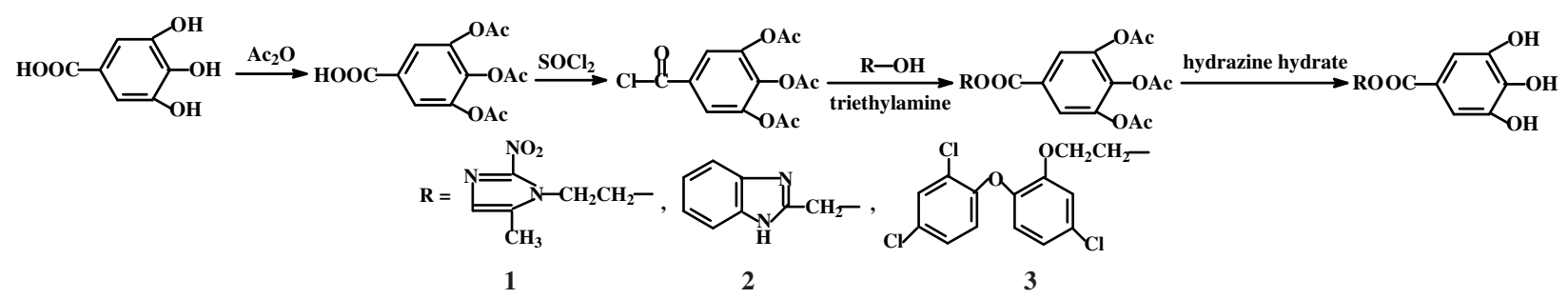

Scheme-I: Synthetic route of the designed gallates by indirect esterification method 
indicate the general procedure of the indirect esterification method. To a stirred solution of TAGC $(6.29 \mathrm{~g}, 0.02 \mathrm{~mol})$ and 2-methylol benzimidazole $(2.96 \mathrm{~g}, 0.02 \mathrm{~mol})$ in anhydrous $\mathrm{CH}_{2} \mathrm{Cl}_{2}(250 \mathrm{~mL})$ was added triethylamine $(10.12 \mathrm{~g}, 0.1 \mathrm{~mol})$ at $3{ }^{\circ} \mathrm{C}$. The temperature of $3{ }^{\circ} \mathrm{C}$ was kept for $0.5 \mathrm{~h}$, then, the reaction mixture was allowed to stir for $12 \mathrm{~h}$ at room temperature and a light-rufous solution was obtained. The $\mathrm{CH}_{2} \mathrm{Cl}_{2}$ layer was first washed with $200 \mathrm{~mL}$ of diluted hydrochloric acid $(10 \%, \mathrm{v} / \mathrm{v})$ to remove the unreacted triethylamine and then was washed with distilled water $(100 \mathrm{~mL} \times 3)$. After removal of the water layer, the $\mathrm{CH}_{2} \mathrm{Cl}_{2}$ layer was added to a round flask containing $80 \%$ hydrazine monohydrate $(3.7545 \mathrm{~g}$, $0.06 \mathrm{~mol}$ ) and the mixture was stirred for $0.5 \mathrm{~h}$ at room temperature. Next, glacial acetic acid (3.603 g, $0.06 \mathrm{~mol})$ in $100 \mathrm{~mL}$ distilled water was added and the mixture was then stirred for 3 min. After filtration, the solid product was washed with distilled water $(50 \mathrm{~mL} \times 3)$ and the $\mathrm{CH}_{2} \mathrm{Cl}_{2}$ layer of the filtrate was also washed with distilled water $(50 \mathrm{~mL} \times 3)$, dried over anhydrous $\mathrm{Na}_{2} \mathrm{SO}_{4}$ and evaporated to dryness. The residue and solid product after filtration was added together and recrystallized with the mixed solvent of ethanol and distilled water $(3: 7, v / v)$. The separated white product (compound 1) was vacuum dried and the yield is $83.3 \%$. m.p. $238-240{ }^{\circ} \mathrm{C}$. Anal. calcd. $(\%)$ for $\mathrm{C}_{15} \mathrm{H}_{12} \mathrm{~N}_{2} \mathrm{O}_{5}: \mathrm{C}, 60.00 ; \mathrm{H}, 4.03 ; \mathrm{N}, 9.33$. Found (\%): C, 60.23; H, 4.24; N, 8.95. Slected IR data $\left(\mathrm{KBr}, \mathrm{cm}^{-1}\right)$ : $3509.29\left(v_{\mathrm{NH}}\right), 3455.79,3409.16\left(\mathrm{v}_{\mathrm{OH}}\right), 1689.40\left(\mathrm{v}_{\mathrm{C}=\mathrm{O}}\right), 1631.02$ $\left(v_{\mathrm{C}=\mathrm{N})}, 1604.95,1590.63,1455.64\left(\mathrm{v}_{\mathrm{Ar}}\right), 1434.59\left(\delta_{\mathrm{CH}_{2}}\right), 1345.68\right.$, $1239.06\left(v_{\mathrm{C}-\mathrm{N}}\right), 1207.30\left(\mathrm{v}_{\text {asC-O-C }}\right), 1032.54\left(\mathrm{v}_{\mathrm{sC}-\mathrm{O}-\mathrm{C}}\right), 859.95$, $750.39\left(v_{\mathrm{Ar}-\mathrm{H}}\right) .{ }^{1} \mathrm{H} \mathrm{NMR}\left(600 \mathrm{MHz},\left(\mathrm{CD}_{3}\right)_{2} \mathrm{SO}\right), \delta_{\mathrm{ppm}}: 3.45(\mathrm{~m}$, $\mathrm{CH}_{2}$ of $\left.\mathrm{C}_{2} \mathrm{H}_{5} \mathrm{OH}\right), 5.44$ (s, 2H, $\left.-\mathrm{CH}_{2} \mathrm{O}-\right), 7.05$ (d, 2H, Ph), 7.21 (m, 2H, Ph), 7.58 (s, 2H, Ph), 9.09 (s, 1H, Ph-OH), 9.36 (s, $2 \mathrm{H}, \mathrm{Ph}-\mathrm{OH}), 12.65$ (s, 1H, NH). ${ }^{13} \mathrm{C} \mathrm{NMR}(600 \mathrm{MHz}$, $\left.\left(\mathrm{CD}_{3}\right)_{2} \mathrm{SO}\right), \delta_{\mathrm{ppm}}$ : $60.13\left(-\mathrm{CH}_{2} \mathrm{O}-\right), 109.35(\mathrm{Ph}), 119.15(\mathrm{Ph})$, $122.48(\mathrm{Ph}), 122.53(\mathrm{Ph}), 122.59(\mathrm{Ph}), 139.32(\mathrm{Ph}), 146.11$ $(\mathrm{Ph}), 149.90(\mathrm{Ph}), 165.91(-\mathrm{COO}-)$.

Compound 2, the product of indirect esterification between 5-methyl-2-nitro-imidazole-1-ethanol and gallic acid, is a white solid and the total yield is $87.5 \%$. m.p. $216-217^{\circ} \mathrm{C}$. Anal. calcd. (\%) for $\mathrm{C}_{13} \mathrm{H}_{13} \mathrm{~N}_{3} \mathrm{O}_{7}$ : C, 48.30; $\mathrm{H}, 4.05 ; \mathrm{N}, 13.00$. Found (\%): C, 47.35; H, 4.78; N, 12.59. Slected IR data $\left(\mathrm{KBr}, \mathrm{cm}^{-1}\right)$ : $3373.00\left(\mathrm{v}_{\mathrm{OH}}\right), 1693.44\left(\mathrm{v}_{\mathrm{C}=\mathrm{O}}\right), 1608.05\left(\mathrm{v}_{\mathrm{C}=\mathrm{N}}\right), 1539.33$, $1458.73\left(v_{\mathrm{Ar}}\right), 1429.91\left(\delta_{\mathrm{CH}_{3}}\right), 1333.70\left(\mathrm{v}_{\mathrm{NO}_{2}}\right), 1236.18\left(\mathrm{v}_{\text {asC-O-C }}\right)$, $1046.62\left(v_{\text {sC-O-C }}\right), 856.30\left(\delta_{\mathrm{Ar}-\mathrm{H}}\right) .{ }^{1} \mathrm{H}$ NMR $(600 \mathrm{MHz}$, $\left.\left(\mathrm{CD}_{3}\right)_{2} \mathrm{SO}\right), \delta_{\mathrm{ppm}}: 2.46\left(\mathrm{~s}, 3 \mathrm{H}, \mathrm{CH}_{3}\right), 4.56\left(\mathrm{t}, 2 \mathrm{H},-\mathrm{NCH}_{2}-\right), 4.67(\mathrm{t}$, $\left.2 \mathrm{H},-\mathrm{CH}_{2} \mathrm{O}-\right), 6.85(\mathrm{~s}, 2 \mathrm{H}, \mathrm{Ph}), 8.05(\mathrm{~s}, 1 \mathrm{H},=\mathrm{CH}$ of imidazole $)$, 9.33 (s, 2H, Ph-OH) 9.04 (s, 1H, Ph-OH). ${ }^{13} \mathrm{C} \mathrm{NMR}(600 \mathrm{MHz}$, $\left.\left(\mathrm{CD}_{3}\right)_{2} \mathrm{SO}\right), \delta_{\mathrm{ppm}}: 14.45\left(\mathrm{CH}_{3}\right), 45.53\left(-\mathrm{NCH}_{2}-\right), 62.70\left(-\mathrm{CH}_{2} \mathrm{O}-\right)$, $108.98(\mathrm{Ph}), 119.04(\mathrm{Ph}), 133.62$ (=CH of imidazole), 138.95 $(\mathrm{Ph}), 139.25$ (=CH of imidazole), $146.04(\mathrm{Ph}), 151.93(\mathrm{~N}=\mathrm{C}$ of imidazole)), 165.87 (COO).

Compound 3 , the product of indirect esterification between 2,4,4'-trichloro-2'-hydroxy ethyoxyl diphenyl ether and gallic acid, is a white solid and the total yield is $84.9 \%$. m.p. 124$126{ }^{\circ} \mathrm{C}$. Anal. calcd. (\%) for $\mathrm{C}_{21} \mathrm{H}_{15} \mathrm{O}_{7} \mathrm{Cl}_{3}$ : C, 51.93; $\mathrm{H}, 3.11$. Found (\%): C, 52.88; H, 3.91. Slected IR data $\left(\mathrm{KBr}, \mathrm{cm}^{-1}\right)$ : 3363.37 $\left(\mathrm{V}_{\mathrm{Ar}}-\mathrm{OH}\right), 1694.27\left(\mathrm{~V}_{\mathrm{C}=\mathrm{O}}\right), 1533.03,1494.89\left(\mathrm{~V}_{\mathrm{Ar}}\right)$, $1471.23\left(\delta_{\mathrm{CH}_{2}}\right), 1306.28\left(\mathrm{~V}_{\text {asAr }}{ }^{-\mathrm{O}-\mathrm{C}}\right), 1220.36\left(\mathrm{~V}_{\text {asC-O-C }}\right), 1116.28$, $767.06\left(\mathrm{v}_{\mathrm{Ar}-\mathrm{Cl}}\right), 1097.59\left(\mathrm{v}_{\mathrm{sC}-\mathrm{O}-\mathrm{C}}\right), 1029.28\left(\mathrm{v}_{\mathrm{sAr}-\mathrm{O}-\mathrm{C}}\right), 868.42$,
795.63, $749.15\left(\delta_{\mathrm{Ar}-\mathrm{H}}\right) .{ }^{1} \mathrm{H}$ NMR $\left(600 \mathrm{MHz},\left(\mathrm{CD}_{3}\right)_{2} \mathrm{SO}\right), \delta_{\mathrm{ppm}}$ : 4.34 (t, $\left.4 \mathrm{H}, \mathrm{OCH}_{2} \mathrm{CH}_{2} \mathrm{O}-\right), 6.79$ (d, 1H, Ph), 6.91 (s, 2H, Ph), 7.06 (d, 1H, Ph), 7.08 (d, 1H, Ph), 7.18 (d, 1H, Ph), 7.37(s, 1H, Ph), 8.97 (s, 1H, Ph-OH), 9.24(s, 2H, Ph-OH). ${ }^{13} \mathrm{C}$ NMR $\left(600 \mathrm{MHz},\left(\mathrm{CD}_{3}\right)_{2} \mathrm{SO}\right), \delta_{\mathrm{ppm}}: 62.84\left(-\mathrm{CH}_{2} \mathrm{O}-\right), 67.59\left(-\mathrm{OCH}_{2}-\right)$, $109.13(\mathrm{Ph}), 115.57(\mathrm{Ph}), 119.17(\mathrm{Ph}), 119.45(\mathrm{Ph}), 121.78$ $(\mathrm{Ph}), 122.65(\mathrm{Ph}), 124.05(\mathrm{Ph}), 127.62(\mathrm{Ph}), 128.70(\mathrm{Ph})$, $130.07(\mathrm{Ph}), 130.12(\mathrm{Ph}), 139.01(\mathrm{Ph}), 143.24(\mathrm{Ph}), 145.96$ $(\mathrm{Ph}), 150.78(\mathrm{Ph}), 152.25(\mathrm{Ph}), 166.12$ (-COO-).

Crystal structure determination: A single crystal of a compound was mounted on a glass fiber. X-Ray diffraction intensity data were collected on an Xcalibur, Eos diffractometer equipped with a graphite-monochromated $\mathrm{MoK}_{\alpha}$ radiation by using the $\omega-2 \theta$ scan technique. The Multi-scan/CrysAlisPro ${ }^{31}$, Oxford Diffraction Ltd., was applied for the data reduction and absorption correction. All the structures were solved by direct methods and refined by full matrix least squares methods using SHELX-97 program $^{32}$. The hydrogen atoms of hydroxyl groups that were located in a difference Fourier map were limitedly refined with isotropic temperature factors and the other hydrogen atoms that were added in their calculated position were refined using a riding model $^{32}$.

Antimicrobial activity determination: The evaluation of the inhibitory effect of the synthesized gallates and their original compounds was carried out by the inhibition zone method $^{33}$. The diameters of filter-paper discs are $22 \mathrm{~mm}$ and the concentration of the tested compounds is $50 \mathrm{mg} / \mathrm{mL}$. The tested microbes contained Escherichia coli, Staphylococcus aureus, Viscous red round yeast, Aspergillus niger and Penicillium citrinum, which were all isolated from mildewed leather ${ }^{33,34}$. Test inoculum of $5 \times 10^{4}$ bacteria/mL and $10^{3}$ yeasts or spores/mL was applied. Nutrient Agar and Potato medium were employed as culture media for bacteria and fungi, respectively. The diameters of inhibition zones were tested by a vernier caliper after an incubation period of $24 \mathrm{~h}$ at $37^{\circ} \mathrm{C}$ for bacteria or of $48 \mathrm{~h}$ at $30^{\circ} \mathrm{C}$ for fungi. All experiments were made in duplicate and the results were confirmed in three independent experiments.

\section{RESULTS AND DISCUSSION}

Structure of 2,4,4'-trichloro-2'-hydroxy ethyoxyl diphenyl ether: To obtain the gallate containing the antimicrobial unit of Triclosan, the hydroxyl group was attached to triclosan. The etherification product of triclosan, 2,4,4'-trichloro-2'hydroxy ethyoxyl diphenyl ether (THEDE), was characterized by X-ray single-crystal diffraction. Table- 1 is a summary of the crystal data and structure refinement parameters. Its crystal structure and crystal packing diagram are shown in Fig. 1. The selected bond lengths and bond angles are listed in Table-2. The hydrogen bonds are listed in Table-3.

As shown in Fig. 1, the molecular structure of the synthesized product is different from that of triclosan. The hydrogen atom of phenolic hydroxyl group of triclosan has been successfully substituted by the hydroxyethyl group, which proves that our synthesis procedure is feasible. It can be seen from Table-2 that the bond length of O2-C13 is 1.4324(17) $\AA$, the bond angle of C3-O2-C13 is 117.33(11) ${ }^{\mathbf{0}}$. Furthermore, there is intermolecular hydrogen bonding between the oxygen 


\begin{tabular}{|c|c|c|c|}
\hline \multicolumn{4}{|c|}{$\begin{array}{c}\text { TABLE-1 } \\
\text { RYSTAL DATA AND STRUCTURE REFINEMENT DET } \mathrm{P}\end{array}$} \\
\hline Empirical formula & $\mathrm{Cl}_{4} \mathrm{H}_{11} \mathrm{O}_{3} \mathrm{Cl}_{3}$ & Formula weight & 333.58 \\
\hline Temperature (K) & 145.0 & Crystal system & Monoclinic \\
\hline Space group & $\mathrm{P} 2_{1} / \mathrm{c}$ & $\mathrm{a}(\AA), \mathrm{b}(\AA), \mathrm{c}(\AA)$ & $10.9914(3), 4.71693(10), 27.4699(7)$ \\
\hline$\alpha\left({ }^{\circ}\right), \beta\left({ }^{\circ}\right), \gamma\left({ }^{\circ}\right)$ & $90.00,100.927(2), 90.00$ & Volume $/ \AA^{3}$ & $1398.38(6)$ \\
\hline $\mathrm{Z}, \rho_{\mathrm{calc}}\left(\mathrm{mgmm}^{-3}\right)$ & $4,1.584$ & $\mu\left(\mathrm{mm}^{-1}\right), \mathrm{F}_{(000)}$ & $0.658,680$ \\
\hline Crystal size $\left(\mathrm{mm}^{3}\right)$ & $0.40 \times 0.35 \times 0.35$ & $2 \theta$ range for data collection & $6.04-52.78^{\circ}$ \\
\hline Index ranges & $-13 \leq \mathrm{h} \leq 6,-3 \leq \mathrm{k} \leq 5,-31 \leq 1 \leq 34$ & Reflections collected & 5562 \\
\hline Independent reflections $\left(\mathrm{R}_{\text {int }}\right)$ & $2846(0.0142)$ & Data/restraints/parameters & $2846 / 0 / 182$ \\
\hline Observed reflections & 2561 & Absorption correction & multi-scan \\
\hline Max. and min. transmission & 1.0 and 0.96383 & Refinement method & Full-matrix least-squares on $\mathrm{F}^{2}$ \\
\hline Goodness-of-fit on $\mathrm{F}^{2}$ & 1.047 & Final $R$ indexes $[I>2 \sigma(I)]$ & $\mathrm{R}_{1}=0.0267, \mathrm{wR}_{2}=0.0626$ \\
\hline Final $\mathrm{R}$ indexes [all data] & $\mathrm{R}_{1}=0.0308, \mathrm{wR}_{2}=0.0651$ & Largest diff. peak/hole $\left(\mathrm{e}^{-3}\right)$ & $0.264 /-0.217$ \\
\hline
\end{tabular}

\begin{tabular}{cccccc}
\multicolumn{7}{c}{ TABLE-2 } \\
SELECTED BOND LENGTHS $(\AA)$ AND ANGLES $\left({ }^{\circ}\right)$ FOR THEDE \\
Bond & Length $(\AA)$ & Bond & Length $(\AA)$ & Bond & Length $(\AA)$ \\
\hline C11-C1 & $1.7412(15)$ & O1-C1 & $1.3926(17)$ & O2-C13 & $1.4324(17)$ \\
C12-C8 & $1.7343(15)$ & O1-C7 & $1.3726(17)$ & O3-C14 & $1.4219(17)$ \\
C13-C10 & $1.7461(16)$ & O2-C3 & $1.3653(17)$ & - & - \\
\hline Angle & $\left({ }^{\circ}\right.$ & Angle & $\left({ }^{\circ}\right)$ & Angle & $\left({ }^{\circ}\right)$ \\
\hline C7-O1-C4 & $118.06(11)$ & O2-C3-C4 & $116.50(12)$ & O3-C14-C13 & $110.20(12)$ \\
O2-C3-C2 & $124.78(13)$ & O2-C13-C14 & $107.53(11)$ & C3-O2-C13 & $117.33(11)$ \\
\hline
\end{tabular}

\begin{tabular}{ccccc}
\multicolumn{5}{c}{ TABLE-3 } \\
HYDROGEN BOND LENGTHS $(\AA)$ \\
\hline AND BOND ANGLES $\left({ }^{\circ}\right)$ FOR THEDE \\
\hline D-H $\cdots$ A & D-H $(\AA)$ & H $\cdots$ A $(\AA)$ & D $\cdots$ A $(\AA)$ & $<($ DHA $)\left({ }^{\circ}\right)$ \\
O3-H3 $\cdots$ O $^{1}$ & 0.84 & 1.91 & $2.7217(10)$ & 163.0 \\
\hline Symmetry code: ${ }^{1}-\mathrm{X},-1 / 2+\mathrm{Y}, 1 / 2-\mathrm{Z}$.
\end{tabular}

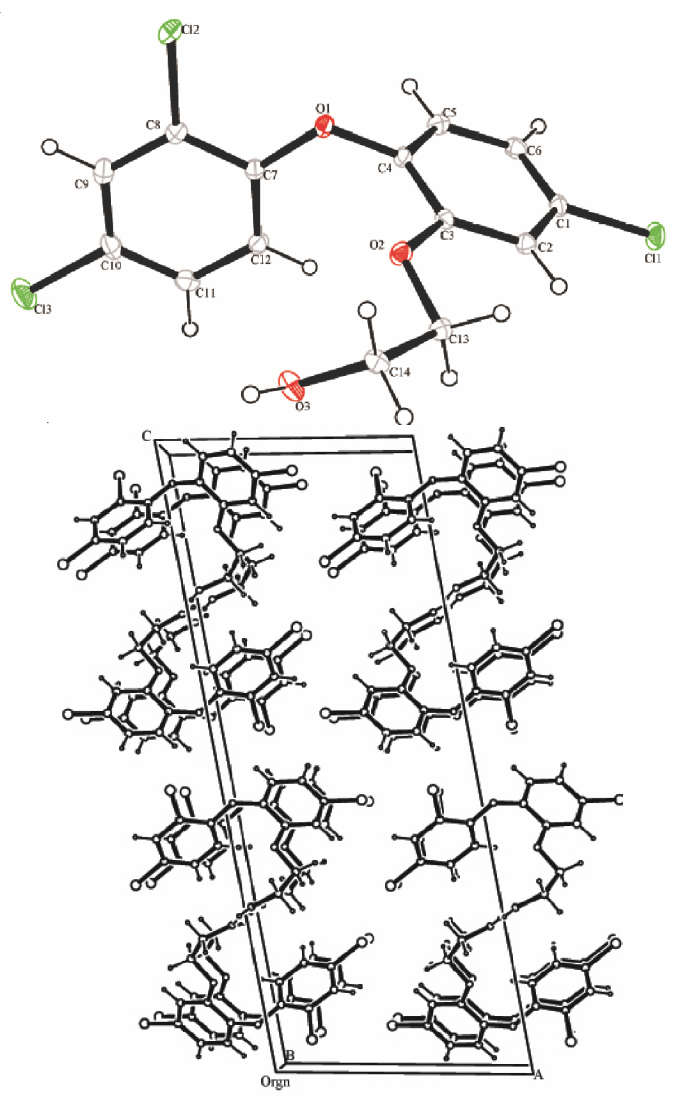

Fig. 1. Molecular structure and crystal packing diagram of THEDE atoms of different two THEDE molecules. From Table-3, the hydrogen bond length of $\mathrm{H} 3 \cdots \mathrm{O} 3^{1}$ is $1.91 \AA$ and the bond angle of $\mathrm{O} 3-\mathrm{H} 3 \cdots \mathrm{O} 3^{1}$ is $163.0^{\circ}$.

Direct esterification method: $p$-Toluenesulfonic acid, which is a frequently-used catalyst for the esterification reaction between gallic acid and lower alcohols ${ }^{1}$, was used for the synthesis of the three gallates. Unfortunately, no expected product was obtained. 2-Methylol benzimidazole and THEDE did not react with gallic acid under our conditions. But, it is interesting that we got a product from the direct esterification reaction between 5-methyl-2-nitro-imidazole-1-ethanol and gallic acid. The X-ray single-crystal diffraction was used to characterize its structure. A summary of the crystal data and structure refinement parameters for the compound of 5-methyl2-nitro-imidazole-1-ethanol and gallic acid (CMG) are given in Table-4. The crystal structure and crystal packing diagram are shown in Fig. 2. The selected bond lengths and bond angles are listed in Table-5. The data in Table- 6 are the intermolecular and intramolecular hydrogen bonds and Fig. 3 shows the threedimension network constructed by hydrogen bonds.

It can be seen from Fig. 2 that the obtained product is not an ester formed by 5-methyl-2-nitro-imidazole-1-ethanol and gallic acid, but an equimolar complex of them. It should be noticed that the complex is not a simple mixture of 5-methyl2-nitro-imidazole-1-ethanol and gallic acid. As shown in Fig. 2, the hydrogen atom of carboxyl group of gallic acid has moved to the imidazole ring of 5-methyl-2-nitro-imidazole-1-ethanol and a N2-H bond was formed.

However, this move did not significantly change the properties of the carboxyl group of gallic acid and the imidazole. As shown in Table-5, the bond lengths of O7-C13 and O8C13 is 1.210 (3) $\AA$ and 1.317(3) $\AA$, respectively, which shows that the former still keep the property of $\mathrm{C}=\mathrm{O}$ double bond and the latter is still a $\mathrm{C}-\mathrm{O}$ single bond. That means that, 


\begin{tabular}{cccc}
\hline & \multicolumn{3}{c}{ TABLE-4 } \\
& \multicolumn{4}{c}{ CRYSTAL DATA AND STRUCTURE REFINEMENT DETAILS FOR CMG } \\
\hline Empirical formula & $\mathrm{C}_{13} \mathrm{H}_{16} \mathrm{~N}_{3} \mathrm{O}_{8}$ & Formula weight & 342.29 \\
Temperature $(\mathrm{K})$ & 293.15 & Crystal system & Monoclinic \\
Space group & $\mathrm{P} 2_{1} / \mathrm{c}$ & $\mathrm{a}(\AA), \mathrm{b}(\AA), \mathrm{c}(\AA)$ & $14.8163(7), 7.1017(4), 14.6837(7)$ \\
$\alpha\left(^{\circ}\right), \beta\left(^{\circ}\right), \gamma\left({ }^{\circ}\right)$ & $90.00,104.599(5), 90.00$ & Volume $\left(\AA^{3}\right)$ & $1495.15(13)$ \\
$\mathrm{Z}, \rho_{\text {calc }}\left(\mathrm{mg} \mathrm{mm}^{-3}\right)$ & $4,1.521$ & $\mu\left(\mathrm{mm}^{-1}\right), \mathrm{F}_{(000)}$ & $0.128,716$ \\
Crystal size $\left(\mathrm{mm}^{3}\right)$ & $0.40 \times 0.40 \times 0.35$ & $2 \theta$ range for data collection & $5.74-52.74^{\circ}$ \\
Index ranges & $-18 \leq \mathrm{h} \leq 12,-7 \leq \mathrm{k} \leq 8,-17 \leq 1 \leq 18$ & Reflections collected & 6336 \\
Independent reflections & $3057\left[\mathrm{R}_{\text {(int) }}=0.0179\right]$ & Data/restraints/parameters & $3057 / 0 / 234$ \\
Goodness-of-fit on $\mathrm{F}^{2}$ & 1.037 & Final R indexes $[\mathrm{I}>2 \sigma(\mathrm{I})]$ & $\mathrm{R}_{1}=0.0639, \mathrm{wR} \mathrm{R}_{2}=0.1769$ \\
Final R indexes [all data] & $\mathrm{R}_{1}=0.0836, \mathrm{wR}_{2}=0.1956$ & Largest diff. peak/hole $\left(\mathrm{e} \AA^{-3}\right)$ & $0.515 /-0.691$ \\
\hline
\end{tabular}

\begin{tabular}{cccccc}
\multicolumn{7}{c}{ TABLE-5 } \\
SELECTED BOND LENGTHS $(\AA)$ AND ANGLES $\left({ }^{\circ}\right)$ FOR CMG \\
\hline Bond & Length $(\AA)$ & Bond & Length $(\AA)$ & Bond & Length $(\AA)$ \\
\hline O3-C6 & $1.417(4)$ & O8-C13 & $1.317(3)$ & N2-C3 & $1.344(4)$ \\
O4-C7 & $1.358(3)$ & N1-C1 & $1.379(4)$ & C2-C3 & $1.320(4)$ \\
O5-C8 & $1.361(3)$ & N1-C2 & $1.352(4)$ & N3-C1 & $1.419(4)$ \\
O6-C9 & $1.367(3)$ & N2-C1 & $1.359(4)$ & C11-C13 & $1.487(4)$ \\
O7-C13 & $1.210(3)$ & - & - & - & - \\
\hline Angle & $\left({ }^{\circ}\right)$ & Angle & $\left({ }^{\circ}\right)$ & Angle & $\left({ }^{\circ}\right)$ \\
C2-N1-C1 & $105.1(2)$ & C3-C2-N1 & $111.5(2)$ & O5-C8-C9 & $118.6(2)$ \\
C3-N2-C1 & $108.7(3)$ & C2-C3-N2 & $107.1(2)$ & O6-C9-C8 & $116.3(2)$ \\
O1-N3-C1 & $118.9(3)$ & O3-C6-C5 & $111.6(2)$ & O7-C13-C11 & $122.2(3)$ \\
O2-N3-O1 & $123.4(3)$ & O4-C7-C8 & $114.8(2)$ & O8-C13-C11 & $123.2(3)$ \\
O2-N3-C1 & $117.6(3)$ & O5-C8-C7 & $121.1(2)$ & - & $114.6(2)$ \\
N2-C1-N1 & $107.6(2)$ & - & - & - & - \\
\hline
\end{tabular}
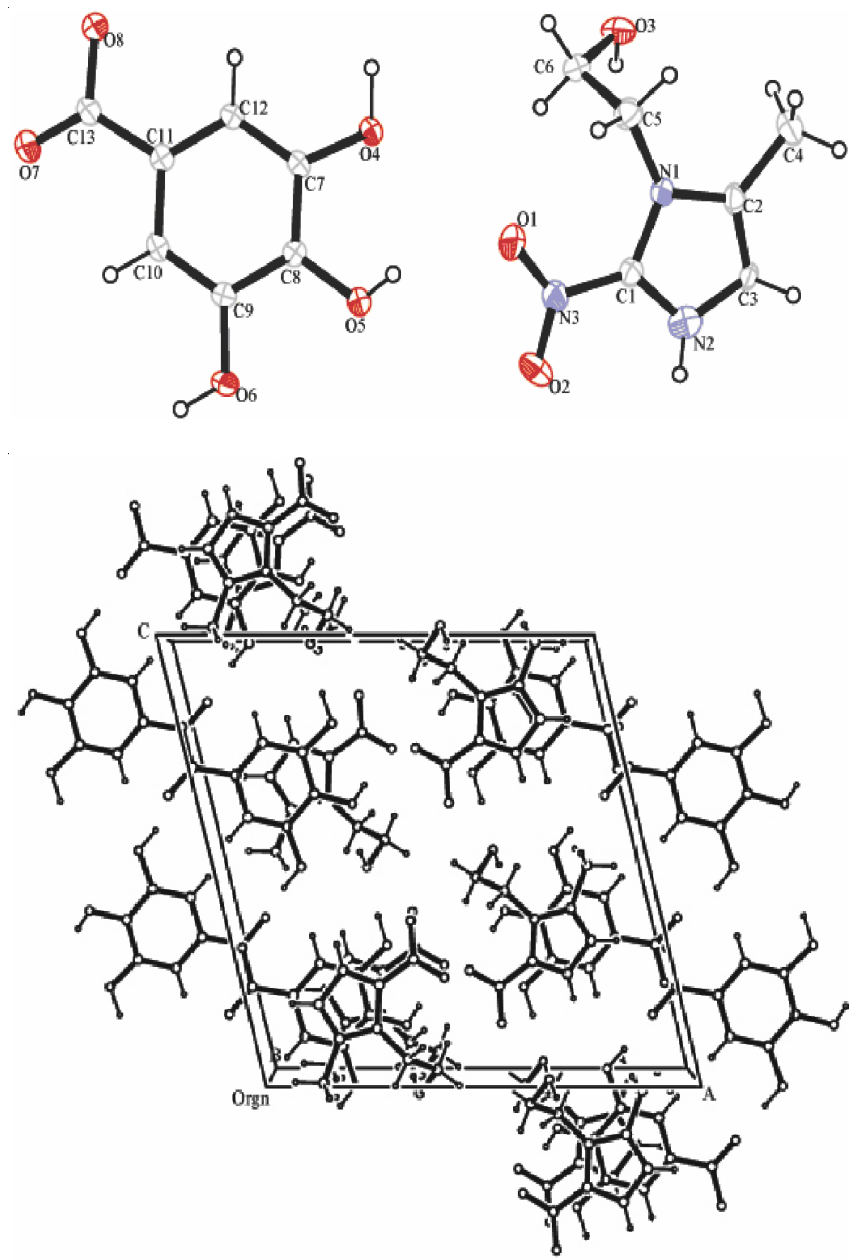

Fig. 2. Molecular structure and crystal packing diagram of $\mathrm{CMG}$

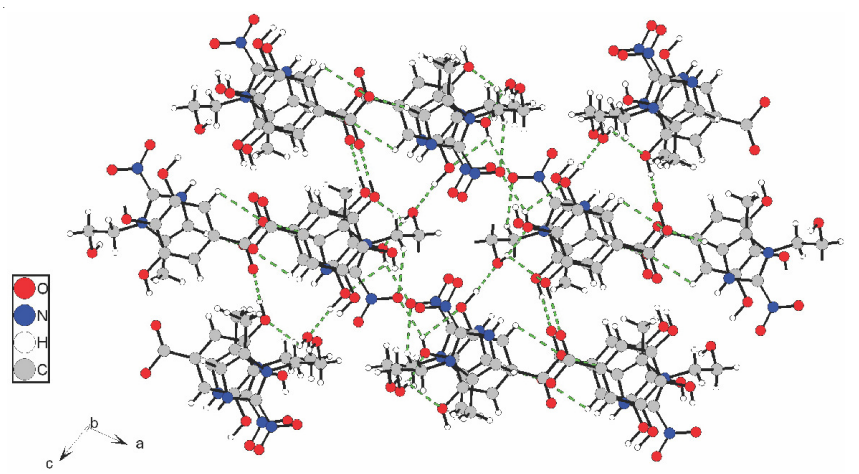

Fig. 3. Three-dimension network constructed by hydrogen bonds for CMG

although the carboxyl group of gallic acid lost its hydrogen atom, it did not change into a carboxylate. Similarly, in the imidazole ring, the bond lengths of N2-C1 and N2-C3 are $1.359(4)$ and 1.344(4), respectively, which shows that the N2-C1 still be a double bond.

The crystal structure analysis (Table-6) shows intramolecular and intermolecular hydrogen bonds in the unit cell. There is intramolecular hydrogen bonding between the hydroxy-oxygen atoms $(\mathrm{O} 4, \mathrm{O} 5)$ of gallic acid and nitro-oxygen atoms of 5-methyl-2-nitro-imidazole-1-ethanol. Thereinto, the hydrogen bond lengths of $\mathrm{H} 5 \cdots \mathrm{O} 1$ and $\mathrm{H} 5 \cdots \mathrm{O} 4$ are 2.12(4) and 2.27(3) $\AA$, respectively and the bond angles of O5-H5 -.O 1 and $\mathrm{O} 5-\mathrm{H} 5 \cdots \mathrm{O} 4$ are $157(4)$ and $116(3)^{\circ}$, respectively. Besides, there exist intermolecular bonding between the hydroxy-oxygen atoms $\left(\mathrm{O} 6, \mathrm{O} 4, \mathrm{O}^{3}, \mathrm{O}^{3}\right)$ and $\left(\mathrm{O}^{1}\right)$ carboxy-oxygen atom of gallic acid and hydroxy-oxygen atoms $\left(\mathrm{O} 3, \mathrm{O}^{2}\right)$ of 5-methyl2-nitro-imidazole-1-ethanol. The bond lengths of $\mathrm{H} 6 \cdots \mathrm{O}^{1}$, $\mathrm{H} 4 \cdots \mathrm{O}^{2}{ }^{2}, \mathrm{H} 3 \cdots \mathrm{O}^{3}$ and $\mathrm{H} 3 \cdots \mathrm{O}^{3}$ are $1.79(5), 1.65(5), 1.98(4)$ 


\begin{tabular}{|c|c|c|c|c|}
\hline \multicolumn{5}{|c|}{$\begin{array}{c}\text { TABLE- } 6 \\
\text { HYDROGEN BOND LENGTHS }(\AA) \\
\text { AND BOND ANGLES }\left({ }^{\circ}\right) \text { FOR CMG }\end{array}$} \\
\hline $\mathrm{D}-\mathrm{H} \cdots \mathrm{A}$ & D-H $(\AA)$ & $\mathrm{H} \cdots \mathrm{A}(\AA)$ & $\mathrm{D} \cdots \mathrm{A}(\AA)$ & $<(\mathrm{DHA})\left({ }^{\circ}\right)$ \\
\hline 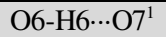 & $0.93(5)$ & $1.79(5)$ & $2.705(3)$ & $166(4)$ \\
\hline O5-H5...O1 & $0.73(4)$ & $2.12(4)$ & $2.808(3)$ & $157(4)$ \\
\hline O5-H5...O4 & $0.73(4)$ & $2.27(3)$ & $2.668(3)$ & $116(3)$ \\
\hline $\mathrm{O} 4-\mathrm{H} 4 \ldots 3^{2}$ & $1.00(4)$ & $1.65(5)$ & $2.640(3)$ & $174(4)$ \\
\hline $\mathrm{O} 3-\mathrm{H} 3 \ldots \mathrm{O}^{3}$ & $0.86(4)$ & $1.98(4)$ & 2.813(3) & $162(4)$ \\
\hline O3-H3...O6 ${ }^{3}$ & $0.86(4)$ & $2.45(4)$ & $3.009(3)$ & 123(3) \\
\hline
\end{tabular}

and 2.45(4) $\AA$, respectively; the bond angles of O6-H6 $\cdots 7^{1}$, $\mathrm{O} 4-\mathrm{H} 4 \cdots \mathrm{O}^{2}, \mathrm{O} 3-\mathrm{H} 3 \cdots \mathrm{O}^{3}$ and O3-H3 $\cdots \mathrm{O}^{3}$ are 166(4), 174(4), 162(4) and $123(3)^{\circ}$, respectively. As shown in Fig. 3, a threedimension network is formed because of the existence of a lot of intramolecular and intermolecular hydrogen bonds in the complex, which are also the reason that we can get the complex. On the contrary, the fact that there is no complex between the other two alcohols (2-methylol benzimidazole and THEDE) and gallic acid is perhaps due to the lack of enough intramolecular and intermolecular hydrogen bonds.

Indirect esterification method: As shown in Scheme-I, the indirect esterification method was used to synthesize the three gallates. The three phenolic hydroxyl groups of gallic acid were firstly protected by three acetyls, then, the obtained trisacetyl gallic acid (TAGA) reacted with sulfoxide chloride to synthesize the trisacetyl-galloyl chloride (TAGC) which can easily react with alcohols to get the trisacetyl gallates. Finally, hydrazine hydrate was used to remove the protecting groups (acetyls) and the expected gallates were obtained successfully. This route is suitable not only for lower alcohols but also for higher or complicated alcohols, although there are many reaction steps. The data of elemental analysis, IR, ${ }^{1} \mathrm{H}$ and ${ }^{13} \mathrm{C}$ NMR for the obtained products in experimental part prove that these compounds are exactly the gallates that we expected.

For the gallate of 2-methylol benzimidazole, compound 2, ethyl acetate was used as the solvent to prepare crystals for the X-ray single-crystal diffraction analysis. The solution was placed in room temperature. After two weeks of slow volatilization, white crystals were obtained for the crystal structure determination. A summary of the crystal data and structure refinement parameters for the compound $\mathbf{2}$ are given in Table7. The crystal structure and crystal packing diagram are shown in Fig. 4. The selected bond lengths and bond angles are listed in Table-8. The data in Table-9 are the intermolecular and intramolecular hydrogen bonds.
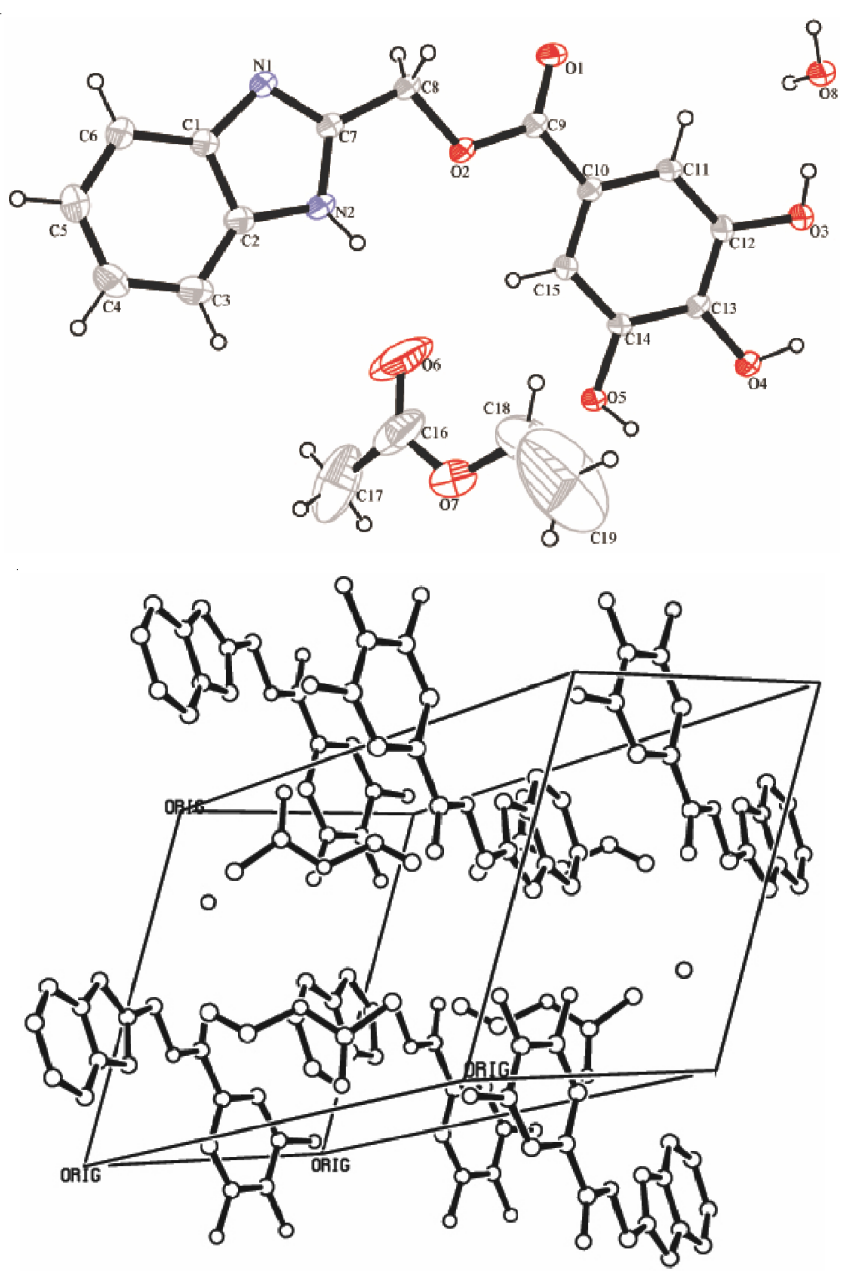

Fig. 4. Molecular structure and crystal packing diagram of the compound

As shown in Fig. 4, there is indeed a ester bond resulted from the esterification reaction between gallic acid and 2-methylol benzimidazole, which further prove that our indirect route is feasible. It can be seen from Table- 8 that, in the ester bond, the bond lengths of O1-C9 and O2-C9 are 1.212(3) and 1.346(3) A, respectively; the bond angles of O1-C9-O2, O1C9-C10, O2-C9-C10 and C9-O2-C8 are 121.9(2), 124.7(2), 113.4(2) and 114.88(18), respectively.

TABLE-7

CRYSTAL DATA AND STRUCTURE REFINEMENT DETAILS FOR THE COMPOUND 2

\begin{tabular}{cccc}
\hline Empirical formula & $\mathrm{C}_{10} \mathrm{H}_{20} \mathrm{~N}_{2} \mathrm{O}_{8}$ & Formula weight & 404.37 \\
Temperature $(\mathrm{K})$, Wavelength $(\AA)$ & $293.15,0.7107$ & Crystal system & Triclinic \\
Space group & $\mathrm{P}-1$ & $\mathrm{a}(\AA), \mathrm{b}(\AA), \mathrm{c}(\AA)$ & $7.5420(3), 9.6464(5), 14.5325(7)$ \\
$\alpha\left(^{\circ}\right), \beta\left(^{\circ}\right), \gamma\left({ }^{\circ}\right)$ & $73.316(4), 83.250(4), 74.361(4)$ & Volume $\left(\AA^{3}\right)$ & $974.37(8)$ \\
$\mathrm{Z}, \rho_{\text {calc }}\left(\mathrm{mg} \mathrm{mm}^{-3}\right)$ & $2,1.378$ & $\mu\left(\mathrm{mm}^{-1}, \mathrm{~F}_{(000)}\right.$ & $0.109,424$ \\
Crystal size $\left(\mathrm{mm}^{3}\right)$ & $0.38 \times 0.15 \times 0.10$ & $2 \theta$ range for data collection & $5.86-50$ \\
Index ranges & $-8 \leq \mathrm{h} \leq 8,-11 \leq \mathrm{k} \leq 10,-17 \leq 1 \leq 17$ & Reflections collected & 7347 \\
Independent reflections $\left(\mathrm{R}_{\text {int }}\right)$ & $3432(0.0179)$ & Data/restraints/parameters & $3432 / 0 / 277$ \\
Observed reflections & 2404 & Absorption correction & multi-scan \\
Max. and Min. transmission & 1.0 and 0.78813 & Refinement method & Full-matrix least-squares on $\mathrm{F}^{2}$ \\
Goodness-of-fit on $\mathrm{F}^{2}$ & 1.035 & Final R indexes $[\mathrm{I}>2 \sigma(\mathrm{I})]$ & $\mathrm{R}_{1}=0.0589, \mathrm{w} \mathrm{R}_{2}=0.1435$ \\
Final R indexes [all data] & $\mathrm{R}_{1}=0.0878, \mathrm{wR}_{2}=0.1620$ & Largest diff. peak/hole $\left(\mathrm{e} \AA^{-3}\right)$ & $0.410 /-0.299$ \\
\hline
\end{tabular}


Vol. 26, No. 2 (2014) Synthesis and Antimicrobial Activity of Three Gallates Containing Imidazole, Benzimidazole and Triclosan Units 519

\begin{tabular}{cccccc}
\hline \multicolumn{7}{c}{ TABLE-8 } \\
\hline SELECTED BOND LENGTHS $(\AA)$ AND ANGLS $\left({ }^{\circ}\right)$ FOR THE COMPOUND 2 \\
\hline Bond & Length $(\AA)$ & Bond & Length $(\AA)$ & Bond & Length $(\AA)$ \\
\hline O1-C9 & $1.212(3)$ & N1-C1 & $1.392(3)$ & N2-C7 & $1.352(3)$ \\
O2-C8 & $1.436(3)$ & N1-C7 & $1.309(3)$ & C7-C8 & $1.483(4)$ \\
O2-C9 & $1.346(3)$ & N2-C2 & $1.379(4)$ & C9-C10 & $1.470(3)$ \\
O3-C12 & $1.364(3)$ & O4-C13 & $1.360(3)$ & O5-C14 & $1.369(3)$ \\
\hline Angle & $\left({ }^{\circ}\right)$ & Angle & $\left({ }^{\circ}\right)$ & Angle & $\left({ }^{\circ}\right)$ \\
\hline C9-O2-C8 & $114.88(18)$ & N1-C7-C8 & $123.0(2)$ & O1-C9-O2 & $121.9(2)$ \\
C7-N1-C1 & $105.1(2)$ & N2-C7-C8 & $124.6(2)$ & O1-C9-C10 & $124.7(2)$ \\
C7-N2-C2 & $107.8(2)$ & O2-C8-C7 & $107.65(19)$ & O2-C9-C10 & $113.4(2)$ \\
N1-C7-N2 & $112.4(2)$ & - & - & - & - \\
\hline
\end{tabular}

\begin{tabular}{|c|c|c|c|c|}
\hline \multicolumn{5}{|c|}{$\begin{array}{c}\text { TABLE-9 } \\
\text { HYDROGEN BOND LENGTHS ( }(\AA) \text { AND } \\
\text { BOND ANGLES }\left({ }^{\circ}\right) \text { FORTHE COMPOUND } 2\end{array}$} \\
\hline D-H...A & $\mathrm{D}-\mathrm{H}(\AA)$ & $\mathrm{H} \cdots \mathrm{A}(\AA)$ & $\mathrm{D} \cdots \mathrm{A}(\AA)$ & $\angle(\mathrm{DHA})\left(^{\circ}\right)$ \\
\hline $\mathrm{O} 3-\mathrm{H} 3 \cdots \mathrm{O} 8$ & 0.82 & 1.98 & $2.781(3)$ & 164.4 \\
\hline $\mathrm{O} 4-\mathrm{H} 4 \cdots \mathrm{O}^{1}$ & $0.93(4)$ & $1.92(4)$ & $2.788(3)$ & $156(3)$ \\
\hline $\mathrm{O} 5-\mathrm{H} 5 \cdots \mathrm{O} 4$ & 0.82 & 2.31 & $2.743(3)$ & 113.2 \\
\hline $\mathrm{O} 5-\mathrm{H} 5 \cdots \mathrm{N}^{2}{ }^{2}$ & 0.82 & 1.97 & $2.691(3)$ & 146.2 \\
\hline $\mathrm{O} 8-\mathrm{H} 8 \mathrm{C} \cdots \mathrm{O}^{3}$ & $0.87(4)$ & $1.95(4)$ & $2.815(3)$ & $173(4)$ \\
\hline O8-H8D $\cdots \mathrm{O}^{4}$ & $0.86(4)$ & $1.96(4)$ & $2.807(4)$ & $167(4)$ \\
\hline $\mathrm{N} 2-\mathrm{H} 2 \cdots \mathrm{O} 6$ & 0.86 & 2.09 & $2.857(4)$ & 147.4 \\
\hline
\end{tabular}

Symmetry code: ${ }^{1} 2-\mathrm{X},-\mathrm{Y},-\mathrm{Z} ;{ }^{2} 1+\mathrm{X},-1+\mathrm{Y},+\mathrm{Z} ;{ }^{3} 1-\mathrm{X}, 1-\mathrm{Y},-\mathrm{Z} ;{ }^{4} 1-\mathrm{X},-\mathrm{Y},-\mathrm{Z}$

Furthermore, in the crystals of compound 2, there are a water molecule and an ethyl acetate molecule. As shown in Table-9, in the unit cell, there exist intermolecular hydrogen bonds between the hydroxy-oxygen atoms (O3, O4, O5), ester-oxygen atom $\left(\mathrm{O}^{3}\right)$ and nitrogen atoms $\left(\mathrm{N}^{2}, \mathrm{~N} 2\right)$ of imidazole ring in the compound $\mathbf{2}$ molecule, the water-oxgen atom (O8) and ester-oxygen atom (O6) in ethyl acetate molecule. There into, the hydrogen bond lengths of $\mathrm{H} 3 \cdots \mathrm{O} 8$, $\mathrm{H} 4 \cdots \mathrm{O}^{1}, \mathrm{H} 5 \cdots \mathrm{O} 4$ and $\mathrm{H} 5 \cdots \mathrm{N} 1^{2}$ are $1.98 \AA$, 1.92(4) $\AA, 2.31 \AA$ and $1.97 \AA$, respectively and the bond angles of $\mathrm{O} 3-\mathrm{H} 3 \cdots \mathrm{O} 8$, $\mathrm{O} 4-\mathrm{H} 4 \cdots \mathrm{O} 8^{1}, \mathrm{O} 5-\mathrm{H} 5 \cdots \mathrm{O} 4$ and $\mathrm{O} 5-\mathrm{H} 5 \cdots \mathrm{N} 1^{2}$ are $164.4,156(3)$, 113.2 and $146.2^{\circ}$, respectively. The hydrogen bond lengths of $\mathrm{H} 8 \mathrm{C} \cdots \mathrm{O} 1^{3}, \mathrm{H} 8 \mathrm{D} \cdots \mathrm{O}^{4}$ and $\mathrm{H} 2 \cdots \mathrm{O} 6$ are $1.95(4) \AA, 1.96(4) \AA$ and $2.09 \AA$, respectively and the bond angles of $\mathrm{O} 8-\mathrm{H} 8 \mathrm{C} \cdots \mathrm{O} 1^{3}$, O8-H8D $\cdots$ O $^{4}$ and N2-H2 ...O6 are 173(4), 167(4) and $147.4^{\circ}$, respectively.

Antimicrobial activity: The in vitro antimicrobial properties of the new gallates and their original compounds were evaluated against bacteria, yeast and moulds and the obtained results are reported in Table-9. For compound 1, its inhibition zones against bacteria is not as big as that of 5-methyl-2nitro-imidazole-1-ethanol but bigger than that of gallic acid, which shows that the two units have an additive effect against tested bacteria. However, for fungi, especially for Viscous red round yeast, there are significantly synergistic effects because the inhibition zones of $\mathbf{1}$ are bigger than that of its two original compounds.

For compound 2, it exhibits good antibacterial activity that is better than that of its original compounds and has moderate inhibitory effect against fungi which is between the gallic acid and 2-methylol benzimidazole. These results indicate that the two antimicrobial units in compound $\mathbf{2}$ have obviously synergistic inhibitory effect against bacteria and additive effect against fungi.

For compound 3, the two antimicrobial units (triclosan and gallic structures) display obviously additive inhibitory effect against all the tested microbes. But, compound $\mathbf{3}$ exhibits the best antimicrobial activities because, compared with $\mathbf{1}$ and 2, its diameters of inhibition zones against all the tested stains are the biggest.

To sum up, the introduction of antimicrobial units has obvious effect on the antimicrobial activities of gallates. To obtain desired gallates, it is the key to choose properly antimicrobial units.

\section{Conclusion}

In summary, for the synthesis of the three new gallates containing the antimicrobial units of imidazole, benzimidazole and triclosan, respectively, the direct esterification method, where $p$-toluenesulfonic acid was chosen as the catalyst, is not feasible. With regard to the direct esterification reaction of 5-methyl-2-nitro-imidazole-1-ethanol and gallic acid, the obtained product is just a special complex of them where the existence of a lot of intramolecular and intermolecular hydrogen bonds plays a key role for its stabilization. On the contrary, the indirect esterification method shown in Scheme-I can successfully prepare the designed gallates. The synthesized gallates shows different inhibitory effect against different tested microbes, which is mainly decided by the introduced antimicrobial units. Synergistic or additive inhibitory effects are found

TABLE-10

DIAMETERS OF INHIBITION ZONES OF THREE GALLATES AND THEIR ORIGINAL COMPOUNDS (mm)

\begin{tabular}{cccccc}
\hline & Escherichia coli & Staphylococcus aureus & Viscous red round yeast & Aspergillus niger & Penicillium citrinum \\
\hline GA & 32.25 & 33.51 & 23.53 & 22.88 & 22.63 \\
MNIE & 37.70 & 43.55 & 23.75 & 23.13 & 22.66 \\
1 & 34.54 & 35.46 & 30.26 & 23.41 & 22.67 \\
MB & 32.41 & 25.71 & 30.03 & 23.85 & 23.30 \\
2 & 36.07 & 28.78 & 28.22 & 23.80 & 22.66 \\
Triclosan & 58.85 & 53.34 & 45.91 & 32.70 & 30.96 \\
3 & 38.03 & 38.11 & 33.16 & 28.74 & 25.46 \\
\hline
\end{tabular}

GA: gallic acid; MNIE: 5-methyl-2-nitro-imidazole-1-ethanol; MB: 2-methylol benzimidazole. 
for the introduction of the three antimicrobial units of imidazole, benzimidazole and triclosan.

\section{ACKNOWLEDGEMENTS}

The project is financially supported by the National Science Foundation of China (No. 21106088) and the Ph. D. Programs Foundation of Ministry of Education of China (No. 20110181120079).

\section{REFERENCES}

1. C.Y. Bo, L.W. Bi, Z.D. Zhao, Q.G. Zhang, D.M. Li, Y. Gu and J. Wang, Modern Chem. Ind., 28, 393 (2008).

2. Q. He, K. Yao and B. Shi, China Surfact. Deterg. Cosmet., 30, 29 (2000).

3. C. Jo, I.Y. Jeong, N.Y. Lee, K.S. Kim and M.W. Byun, Food Sci. Biotechnol. (Food Sci. Biotechnol.), 15, 317 (2006).

4. C.Y. Bo, L.W. Bi, Z.D. Zhao, D.M. Li, Y. Gu, J. Wang, Q.G. Zhang, Y.M. Wang and Y.H. Zhou, Biomass Chem. Eng., 43, 1 (2009).

5. J.Q. Zhang and K. Yao, Food Ferment. Technol., 46, 19 (2010).

6. O.S. Maldonado, R. Lucas, F. Comelles, M.J. González, J.L. Parra, I. Medina and J.C. Morales, Tetrahedron, 67, 7268 (2011).

7. O. Kamiyama, F. Sanae, K. Ikeda, Y. Higashi, Y. Minami, N. Asano and I. Adachi, A. Kato, Food Chem., 122, 1061 (2010).

8. I. Kubo, K. Fujita, K. Nihei and A. Nihei, J. Agric. Food Chem., 52, 1072 (2004)

9. W.J. Zhang, D.Y. Xiong and X.M. Liu, Appl. Chem. Ind., 39, 1849 (2010).

10. A. Ooshiro, M. Kaji, Y. Katoh, H. Kawaide and M. Natsume, J. Pestic. Sci., 36, 240 (2011).

11. F.L. Hsu, P.S. Chen, H.T. Chang and S.T. Chang, Int. Biodeter. Biodegrad., 63, 543 (2009).

12. S.A. Ibrahim, E.D. Wilson, C.W. Seo, A. Shahbazi and M.M. Salameh, 228th National Meeting of the American-Chemical-Society, Philadelphia, Aug 22-26 (2004).

13. J.H. Chen, Y.M. Wang, D.M. Wu, Z.S. Wu and C.Z. Wang, Chem. Ind. Forest Prod., 25, 6 (2005).

14. K.X. Wu, M.Y. Li, L. Chen and X. Chen, Fine Chem., 15, 9 (1998).
15. J.H. Kwak, J.K. In, M.S. Lee, J.Y. Yu, Y.P. Yun, J.T. Hong, S.J. Lee, S.Y. Seo, S.K. Ahn, Y.G. Suh, B.Y. Hwang, H. Lee, K.H. Min and J.K. Jung, Bull. Korean Chem. Soc., 30, 2881 (2009).

16. C. Frey, M. Pavani, G. Cordano, S. Munoz, E. Rivera, J. Medina, A. Morello, J.D. Maya and J. Ferreira, Comp. Biochem. Physiol. A-Mol. Integr. Physiol., 146, 520 (2007).

17. Y. Xu, G.R. Pang, X.F. Lu, Z.J. Chen, S.T. Sun and J.Z. Song, Chin. J. Ophthalmol., 42, 309 (2006).

18. P.C. Leal, A. Mascarello, M. Derita, F. Zuljan, R.J. Nunes, S. Zacchino and R.A. Yunes, Bioorg. Med. Chem. Lett., 19, 1793 (2009).

19. W.M. Soe, M. Giridharan, R.T.P. Lin, M.K. Sakharkar and K.R. Sakharkar, Lett. Drug Design Discov., 7, 160 (2010).

20. H. Shibata, T. Nakano, M.A.K. Parvez, Y. Furukawa, A. Tomoishi, S. Niimi, N. Arakaki and T. Higuti, Antimicrob. Agents Chemother, 53, 2218 (2009).

21. X.Y. Lu and W.W. Chen, Acta Pharm. Sinica, 22, 586 (1987).

22. Z.P. Xiao, R.Q. Fang, L. Shi, H. Ding, C. Xu and H.L. Zhu, Can. J. Chem., 85, 951 (2007).

23. E. Nomura, A. Hosoda, H. Morishita, A. Murakami, K. Koshimizu, H. Ohigashi and H. Taniguchi, Bioorg. Med. Chem., 10, 1069 (2002).

24. H.B. Gu and W.Y. Chen, China Leather, 34, 12 (2005).

25. W.Y. Chen and G.Y. Li, Tanning Chemistry, Beijing: China Light Industry Press (2004)

26. M. Wang and Y.B. Zhang, Modern Agrochem., 2, 36 (2003).

27. Y. Zhang, S. Yang, B.A. Song and D.Y. Hu, Agrochemicals, 47, 164 (2008).

28. Y.B. Chen, Y.S. Ouyang and X.M. Huang, Industrial Bactericides, Beijing: Chemical Industry Press (2001).

29. W.X. Zhao, J. Shangqiu Teachers College, 18, 76 (2002).

30. S.S. Ma, S. Jiang, X.X. Shao, W. Chen and B.Q. Yang, J. Northwest Univ. (Nat. Sci. Ed.), 40, 821 (2010).

31. CrysAlisPro, Agilent Technologies, Version 1.171.35.11 (release 1605-2011 CrysAlis171.NET) (compiled May 16 2011,17:55:39).

32. G.M. Sheldrick, SHELXS97 and SHELXL97, University of Göttingen, Germany (1997).

33. H.B. Gu, Y. Li, W.Y. Chen and C.Q. Zhao, Leather Sci. Eng., 15, 7 (2005).

34. C.Q. Zhao, H.B. Gu, Y. Cao, R.Q. Zhou, J. Huang and W.Y. Chen, J. Soc. Leather Technol. Chem., 93, 197 (2009). 